\title{
Prevalence of Sclerotinia Stem Rot of Soybeans in the North-Central United States in Relation to Tillage, Climate, and Latitudinal Positions
}

\author{
F. Workneh and X. B. Yang
}

Department of Plant Pathology, Iowa State University, Ames 50011.

Accepted for publication 30 August 2000.

\section{ABSTRACT}

Workneh, F., and Yang, X. B. 2000. Prevalence of Sclerotinia stem rot of soybeans in the north-central United States in relation to tillage, climate, and latitudinal positions. Phytopathology 90:1375-1382.

Since the early 1990s, Sclerotinia stem rot, caused by Sclerotinia sclerotiorum, has caused considerable damage to soybean production in the north-central United States. To determine the extent of its distribution and associated factors, investigations were conducted in 1995 and 1996 in Illinois, Iowa, Minnesota, Missouri, and Ohio. Investigations also were conducted in 1997 and 1998 in Iowa, Minnesota, and Missouri. In each state, soybean fields were randomly selected in collaboration with the National Agricultural Statistics Service. From each field, 20 soybean stems $20 \mathrm{~cm}$ long (from the base) in 1995 and 1996 and full-length stems in 1997 and 1998 were sampled in a zigzag pattern. During the 4-year period, stem samples were collected from 1,983 fields and assessed for the presence or absence of the disease. Of the five states, Sclerotinia stem rot was most prevalent in north-central Iowa and southern Minnesota. Sclerotinia stem rot was not detected in Missouri during the 4-year investigation period. The disease was most prevalent in 1996 and least prevalent in 1995 . The prevalence of the disease was strongly related to cumulative departures from normal maximum and minimum temperatures in July and August. The disease was more prevalent when yearly temperatures were below normal than when they were above normal. In 1996, a year with a cooler-than-normal summer, the disease was detected farther south than in 1995. In both years, the prevalence of the disease was exponentially related to latitudinal positions of the fields $\left(R^{2}=0.93\right.$ and 0.83 for 1995 and 1996, respectively) reflecting the effect of the north-south variations in temperature. During the 4-year period, there was no relationship between precipitation and the prevalence of the disease. The lack of relationship may suggest that there was no shortage of moisture since it is one of the primary factors for disease development. The prevalence of Sclerotinia stem rot was less in no-till than in minimum-till or conventional-till fields $(P=0.001$ and 0.007 , respectively) and greater in minimum-till than in conventional-till fields $(P=0.07)$. Fields that had Sclerotinia stem rot, however, did not differ in incidence of the disease regardless of the tillage system.

Additional keywords: conservation tillage, surface residue, white mold.
Sclerotinia stem rot, caused by Sclerotinia sclerotiorum, is a destructive disease of various economically important crops that occurs on 408 species of plants in many regions of the world (7). The disease is generally favored by a cool climate and, thus, is assumed to be limited to the temperate region or the subtropical region on winter-grown crops (16). Since it was first observed on soybeans in Hungary in 1924, the disease has been reported in many soybean-producing regions of the world, including the United States and Canada (12).

In the United States, Sclerotinia stem rot of soybeans (also known as white mold) was considered to be of minor importance except for localized outbreaks (12). The disease was limited mainly to northern regions where soybean maturity groups 0 to I are grown. Since the early 1990s, however, the prevalence and intensity of the disease in the north-central United States has drawn increased attention from growers and research and extension personnel $(13,28)$. The disease has caused serious problems farther south in maturity group regions I to II (28). In 1994, Sclerotinia stem rot of soybeans was ranked second among soybean diseases causing yield losses in the United States (27).

What triggered the upsurge in importance of Sclerotinia stem rot of soybeans in the north-central United States is not clear. Most published data on the epidemiology of the disease indicate

Corresponding author: X. B. Yang; E-mail address: xbyang@iastate.edu

Publication no. P-2000-0925-01R

(C) 2000 The American Phytopathological Society that prolonged cool, wet conditions are the primary factors in the disease's development $(4,6,24)$. Canopy density, influenced mainly by row spacing, plant architecture, and soil fertility, is one of the primary factors contributing to the occurrence of such conditions and is strongly associated with disease severity $(4,14,17,19,23)$.

Even though Sclerotinia stem rot is primarily a temperate-climate disease, the extent of its latitudinal distribution is not known. Recent observations of severe outbreaks of the disease in maturity group III (28) have raised speculation that warm-climate isolates might have evolved. In addition, it is not known how fluctuations in yearly weather patterns affect the latitudinal distribution of the disease.

Apothecia of $S$. sclerotiorum with stipes longer than $3 \mathrm{~cm}$ are considered rare under field conditions (2), and sclerotia buried deeper than the length of the stipes are, therefore, assumed to be less of a threat to the concurrent crop than those near the soil surface. It is primarily this unique biological feature of the fungus that associates tillage practices with the epidemiology of the disease. Consequently, deep tillage is recommended as a control tactic. The effect of tillage practices on epidemiology of Sclerotinia stem rot, however, is not fully understood. In rapeseed, Williams and Stelfox (25) showed that plowing to $7.6 \mathrm{~cm}$ and $15 \mathrm{~cm}$ significantly reduced carpogenic germination compared with surface cultivation; however, the effect was not maintained the following year. In Nebraska, plowing to a depth of $25 \mathrm{~cm}$ did not reduce disease severity in dry edible beans (18). In soybeans, GarciaGarza et al. (9) observed more apothecial production in minimum tillage than in no-tillage but did not find differences in disease incidence between the tillage treatments. 
Since the beginning of the 1990s, emphasis on farming practices in the north-central United States has shifted from conventional tillage to conservation tillage in which maintenance of at least $30 \%$ of surface residue is targeted for soil conservation purposes (3). In addition, with the advent of drill planters, there has been an increasing shift from wide rows to narrow rows for better weed control. It is not known how the shift in tillage practices affected the prevalence of the disease in the region.

The primary objectives of this study were to determine, first, the prevalence and distribution of Sclerotinia stem rot of soybeans in the north-central United States and, second, the effects of tillage practices and climatic conditions associated with latitudinal ranges on the prevalence and distribution of the disease.

\section{MATERIALS AND METHODS}

Field selection. In 1995 and 1996, investigations were conducted to determine the prevalence of major soybean diseases and pathogens including Sclerotinia stem rot in Illinois, Iowa, Minnesota, Missouri, and Ohio in collaboration with the National Agricultural Statistics Service (NASS) (26). Investigations on prevalence of Sclerotinia stem rot also were conducted in 1997 and 1998 in Iowa, Minnesota, and Missouri. In each state, soybean fields were randomly selected with the use of an area-frame sampling method $(8,22)$. Details of methods of field selection were reported previously (26).

Sample collection. In each of the selected fields, the National Agricultural Statistics Service establishes and maintains two yield-assessment plots, located at randomly selected sites, from which it derives crop growth stages and production estimates. From each field, 20 soybean stems $20 \mathrm{~cm}$ long (from the base) in 1995 and 1996 and full-length stems in 1997 and 1998 were sampled in a zigzag pattern from areas between the two yield assessment plots. The overall zigzag pattern contained 10 corners, and two stems were collected from each corner. Each year, samples were collected between the last week of September and the first

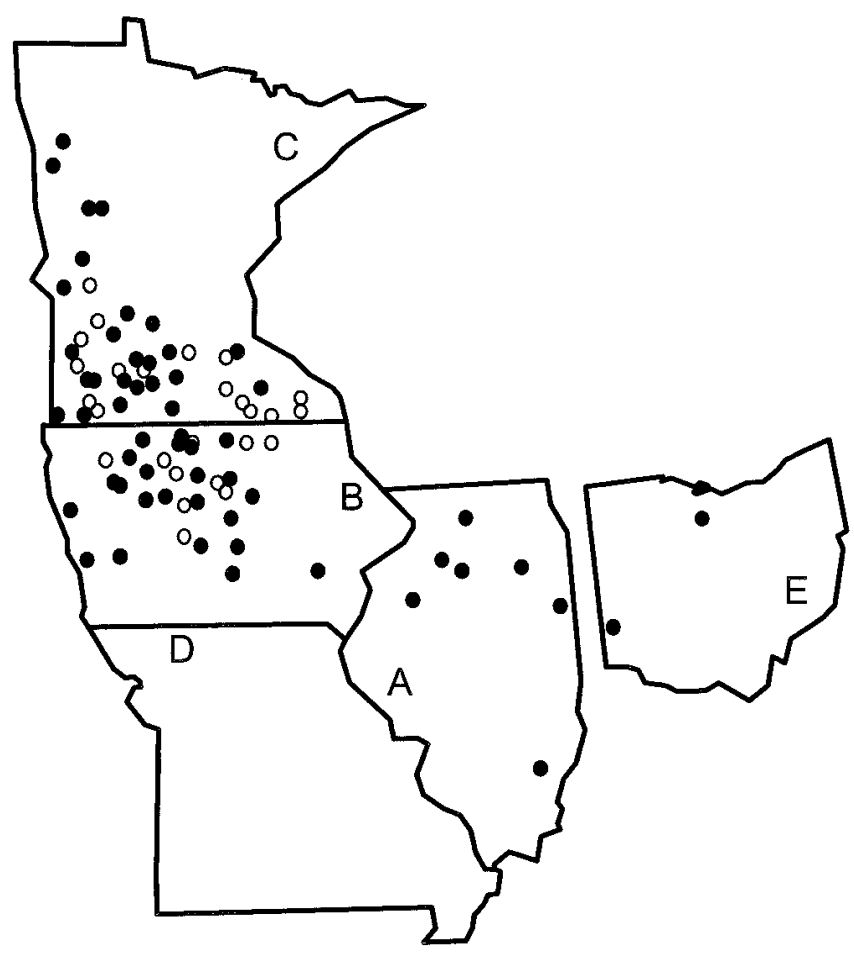

Fig. 1. Distribution of Sclerotinia stem rot of soybeans in Illinois (A), Iowa (B), Minnesota (C), and Ohio (E) in 1995 and 1996 (closed circles), and in 1997 and 1998 (open circles). Sclerotinia stem rot was not detected in Missouri (D) throughout the investigation period. week of November. In 1995 and 1996, in Illinois, Iowa, Minnesota, Missouri, and Ohio, 403, 392, 191, 235, and 245 samples, respectively, were collected. In 1997 and 1998, in Iowa, Minnesota, and Missouri, 219, 158, and 140 samples, respectively, were collected. The $20-\mathrm{cm}$ stem segments were shipped to Ames in large-sized paper bags, while the full-sized stems were shipped in cylindrical mailing tubes. All stem samples with their corresponding tillage and location information were shipped by secondday express mail and stored at $4{ }^{\circ} \mathrm{C}$ until they were assessed.

Because of the soybean-corn rotation schemes practiced by growers in the region, the 1995 and 1996 samples originated from separate fields. Similarly, the 1997 fields were separate from the 1998 fields. In addition, none of the samples collected during the 4-year period originated from the same township, indicating that none of the fields were sampled twice.

Disease assessment. Soybean stems infected with S. sclerotiorum exhibit distinct, visually identifiable signs and symptoms. The fungus produces masses of cottony mycelium on the outside of infected stems. At the latter stage of disease development, sclerotia are produced both on the outside and inside of the stems. Infected stems may have a bleached appearance. In this study, each stem was observed for the presence or absence of the typical cottony mycelial mass of the fungus on the outside of each stem or stem bleaching if sign of the fungus was not obvious. The stems were also split longitudinally and checked for the presence or absence of sclerotia in the pith. A few of the stem samples with signs and symptoms that could not be visually identified were verified by isolation on acidified potato dextrose agar.

Tillage categories. Tillage systems are classified into several categories on the basis of the amount of surface residue (3). Conservation tillage systems are practices that maintain greater than $30 \%$ residue after planting and include no-till, mulch-till, and ridge-till. Tillage practices that maintain 15 to $30 \%$ residues are categorized as reduced-till or minimum-till, whereas those that maintain less than $15 \%$ residue cover are classified as conventional-till. Tillage terms such as reduced-till, minimum-till, and mulch-till are loosely, and often interchangeably, used by farmers and agricultural professionals, even though there are strict definitions based primarily on the amount of surface residues. It often is difficult to distinguish the various forms of tillage practices that range between conventional-till and no-till. For our research, tillage information for individual fields was obtained from farmers by NASS during an interview conducted before data collection. Fields that were not either conventional-till or no-till but received various degrees of tillage operations and had various amounts of surface residue ranging between that of no-till and conventionaltill were designated minimum-till.

Data analyses. In this paper, the term prevalence is used to describe the percentage of fields in which the disease was detected, and the term incidence is used to describe the percentage of samples from a field in which the disease was detected (29). Normal maximum or minimum air temperature described here is a 30-year average (1961 to 1991). To determine the effect of temperature and precipitation on prevalence of the disease, five locations each in Iowa (Ames, Audubon, Eldora, Mason City, and Spencer) and Minnesota (Glenwood, Marshall, Redwood Falls, Waseca, and Windom) were arbitrarily selected to represent their respective states. Iowa and Minnesota were selected because the disease was more prevalent in these two states than the other states during the 4-year period and the selected locations were within the boundaries of the disease distribution. In most soybean fields, infection by $S$. sclerotiorum and subsequent disease development occur during July and August following flowering and canopy closure. Air temperature and precipitation data for the selected locations for July and August of each year were obtained from Midwest Climate Center (Champaign, IL), a subdivision of the National Climatic Data Center (Asheville, NC). To determine the effect of year-to-year variations in temperature on the prevalence of the 
disease, the maximum and minimum daily temperatures in July and August of each year of the 4-year period were compared with the monthly normal temperatures. Cumulative departures of the daily maximum and minimum temperatures from the monthly normal temperature were calculated for each location as

$$
\mathrm{CD}=\sum_{i=1}^{31}\left[x_{i}-y\right]
$$

in which $\mathrm{CD}$ is cumulative departure, $x$ is daily minimum or maximum temperature for July or August, and $y$ is normal minimum or maximum temperature for July or August. The mean of the cumulative departures for all locations in each state for each of the 4 years then were related to the prevalence of the disease with use of regression. Precipitation was also treated as described above. Data for daily precipitation for July and August was collected from each of the stations and compared with normal monthly precipitation. The relationships between departures from the monthly normal precipitation and the prevalence of the disease were then determined with the use of regression.

To determine the effect of latitudinal positions on the prevalence of the disease, soybean fields between $37^{\circ} \mathrm{N}$ (southern Missouri) and $49^{\circ} \mathrm{N}$ (northern Minnesota) were divided into six latitudinal categories at $2^{\circ}$ intervals. The relationship between the prevalence data originated from the field categories and the latitudinal positions was then determined with use of regression. For this particular analysis, only the 1995 and 1996 data were used because latitudinal and longitudinal positions of the 1997 and 1998 fields were not available.

For assessment of the effects of tillage practices on prevalence of Sclerotinia stem rot, the data could not be analyzed by year or by state separately because there were not enough samples from no-till fields with sclerotinia stem rot, resulting in many empty cells. A test for homogeneity of ratio (11) showed that the data can be pooled over all the states and years and summarized by tillage categories. Differences in prevalence of the disease among the tillage categories were determined with the use of a chi-square test. All statistical analyses were conducted with SAS software (SAS Institute, Cary, NC).

\section{RESULTS}

Sclerotinia stem rot of soybean was observed in all the states except Missouri. The distribution of the disease appears to be more clustered in north-central Iowa and southern Minnesota than in the rest of the sampled region (Fig. 1). In all the states (where the disease was observed) except Ohio, the disease was most prevalent in 1996 and least in 1995 (Fig. 2). In 1996, the prevalence of the disease ranged from $0.8 \%$ in Ohio to $19.5 \%$ in Minnesota. In each year of the 4-year investigation, Minnesota consistently had the greatest prevalence of the disease.

The minimum and maximum July and August air temperature data from both Iowa and Minnesota showed that 1996 was the coolest of the 4 years and 1995 the warmest. For example, the mean, normal monthly maximum temperature for the five locations in Iowa was $28.8^{\circ} \mathrm{C}$ for July and $27.2^{\circ} \mathrm{C}$ for August. In 1996, the daily maximum temperature for the 62-day period (July and August) was either less than or equal to the normal maximum temperature $82 \%$ of the time (Fig. 3), whereas in 1995, the daily maximum temperature was either less than or equal to the monthly normal temperature $40 \%$ of the time. Departures of the daily minimum temperatures from normal minimum temperatures followed similar patterns for both months.

There was a strong relationship between cumulative departures from normal maximum or minimum temperatures and the percentage of fields where Sclerotinia stem rot was detected $\left(R^{2}=\right.$ 0.95 and 0.96 for maximum and minimum temperature, respectively, in Iowa and $R^{2}=0.98$ and 0.86 for maximum and minimum temperatures, respectively, in Minnesota (Table 1 and Fig. 4A and
B). In both Iowa and Minnesota, years with negative cumulative departures were associated with greater prevalence of the disease than years with positive cumulative departures.

As expected, the normal maximum temperature during July and August was strongly related to latitudinal positions (Fig. 5), decreasing with increasing latitude. The selected location at $48^{\circ} \mathrm{N}$ (northern Minnesota) was cooler by approximately $5^{\circ} \mathrm{C}$ than the location at $37^{\circ} \mathrm{N}$ (southern Missouri). The optimum temperature range and the upper limit for Sclerotinia stem rot development was reported by various workers to be 20 to $25^{\circ} \mathrm{C}$ and $30^{\circ} \mathrm{C}$, respectively $(1,2,5,15,24)$. In 1995 , during the warmest of the 4 years, the $30^{\circ} \mathrm{C}$ limit was around $42^{\circ} \mathrm{N}$. In 1996 , however, during the coolest of the 4 years, the $30^{\circ} \mathrm{C}$ upper limit shifted down to below $38^{\circ} \mathrm{N}$ (Fig. 6).

The effect of the shift in the upper temperature limit for disease development was demonstrated by the prevalence of the disease in 1995 and 1996. In 1995, the disease was not detected below $41^{\circ} \mathrm{N}$. In 1996 , however, the disease was detected at $39^{\circ} \mathrm{N}$, indicating the latitudinal shift in disease development as a result of the cool weather. Between $39^{\circ} \mathrm{N}$ and $49^{\circ} \mathrm{N}$, the percentage of fields in which the disease was detected varied from 0 to $25 \%$ in 1995 and from 0.68 to $50 \%$ in 1996 . At every latitude, the prevalence of the disease was greater in 1996 than in 1995. In both years, there were exponential relationships between latitude and the square root of the percentage of fields in which the disease was detected (Table 2 and Fig. 7A). The number of samples at each latitude was weighted on soybean acreage (Fig. 7B), and in both years, even though there were relatively few samples, the prevalence of the disease was greatest in the extreme north.

In contrast to temperature, there was no evidence of a relationship between precipitation and prevalence of Sclerotinia stem rot. For example, in 1995, the frequency and amount of precipitation was 18 days and $190 \mathrm{~mm}$, respectively, in Iowa. In 1996, the frequency and amount of precipitation was 17 days and $195 \mathrm{~mm}$, respectively (average of five locations). During the 4-year period, however, Sclerotinia stem rot was most prevalent in 1996 and least prevalent in 1995. Overall, the amount of precipitation for July and August ranged from $105 \mathrm{~mm}$ in 1997 to $195 \mathrm{~mm}$ in

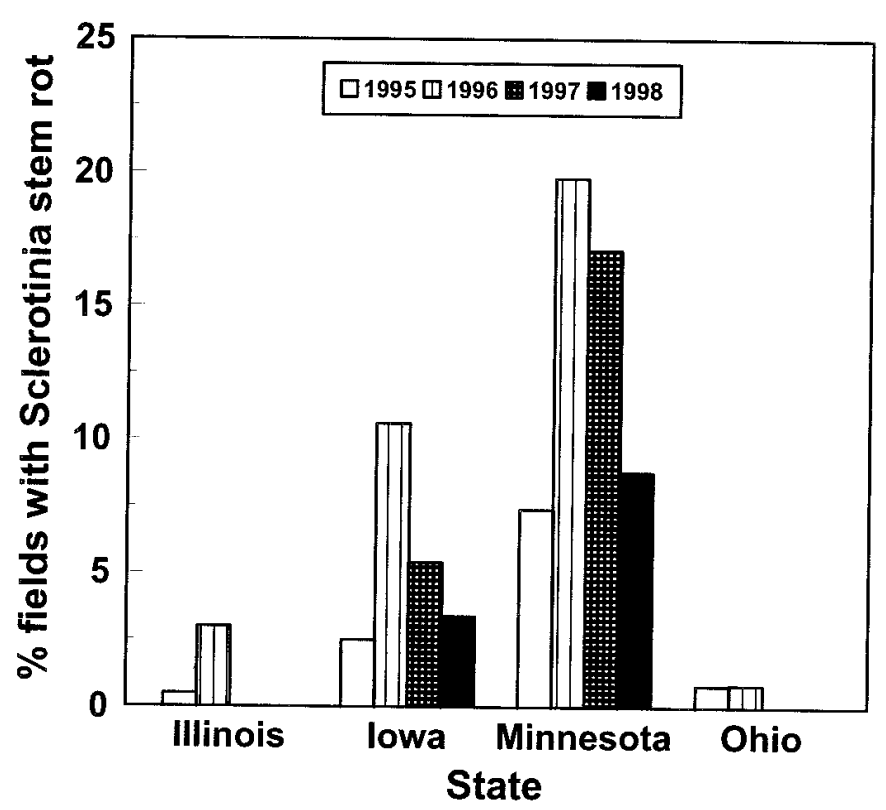

Fig. 2. Percentage of fields with Sclerotinia stem rot in Illinois, Iowa, Minnesota, and Ohio. The total number of samples collected from Illinois was 203 and 199 in 1995 and 1996 respectively; from Iowa, 191, 196, 109, and 110 from 1995 to 1998, respectively; from Minnesota, 94, 95, 70, and 88 from 1995 to 1998, respectively; from Ohio, 124 and 121 in 1995 and 1996, respectively. Investigations were not conducted in Illinois and Ohio in 1997 and 1998. 
1996. The frequency of precipitation ranged from 17 days in 1996 to 23.5 days in 1998 .

In each of the 4 years, the prevalence of sclerotinia stem rot was numerically less in no-till fields than in conventional or minimumtill fields (Fig. 8), and the overall pooled result showed that the prevalence of the disease was significantly less in no-till fields than in conventional-till $(P=0.007)$ or minimum-till fields $(P=$ 0.001 , Fig. 9$)$. There was also a greater prevalence of the disease in minimum-till fields than in conventional-till fields $(P=0.07)$. Throughout the investigation, there were only eight samples from ridge-till fields, none of which had Sclerotinia stem rot. The data from these samples were not included in any of the analyses. In fields where Sclerotinia stem rot was detected, the incidence of the disease ranged from $10.5 \%$ in no-till fields to $13.5 \%$ in mini- mum till-fields, and there was no difference between the tillage practices in disease incidence.

\section{DISCUSSION}

The regional study demonstrated that Sclerotinia stem rot of soybean was more prevalent in Iowa and Minnesota than in Illinois or Ohio. The disease was not observed in Missouri in any year of the 4-year investigation. In the states where sclerotinia stem rot was observed, the prevalence was greatest in 1996 and least in 1995 with the exception of Ohio.

The year-to-year variation in prevalence of the disease during the 4-year period was strongly related to yearly fluctuations of daily air temperatures during July and August. The prevalence of
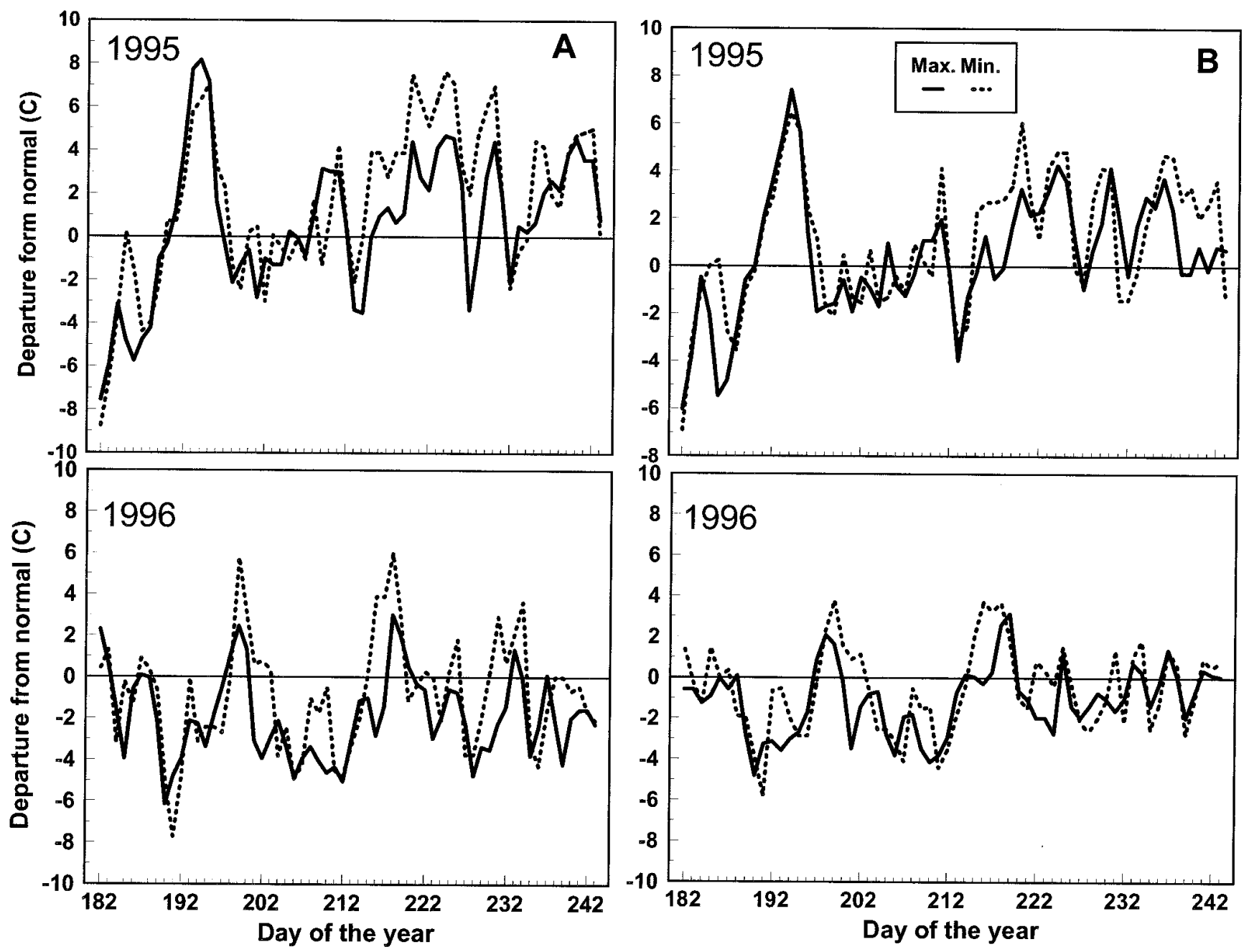

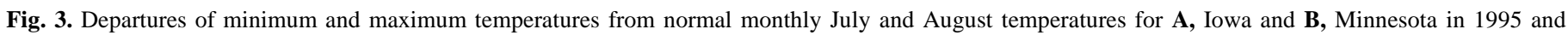

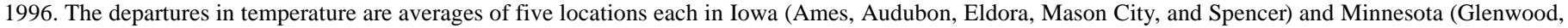
Marshall, Redwood Falls, Waseca, and Windom).

TABLE 1. Parameter estimates for the exponential model $\left(Y=a \times e^{\mathrm{bx}}\right)$ for relationships between prevalence of Sclerotinia stem rot and cumulative departures of daily maximum and minimum temperatures from monthly normal temperatures in Iowa and Minnesota from 1995 to 1998

\begin{tabular}{|c|c|c|c|c|c|c|c|}
\hline \multirow[b]{2}{*}{ Model } & \multicolumn{7}{|c|}{ Parameter estimates } \\
\hline & $a$ & Lower limit ${ }^{\mathrm{a}}$ & Upper limit & $b$ & Lower limit & Upper limit & $R^{2}$ \\
\hline \multicolumn{8}{|l|}{ Iowa } \\
\hline Maximum & 1.683 & -0.983 & 4.348 & -0.015 & -0.030 & 0.000 & 0.95 \\
\hline \multicolumn{8}{|l|}{ Minnesota } \\
\hline Maximum & 9.584 & 6.272 & 12.897 & -0.009 & -0.145 & -0.004 & 0.98 \\
\hline Minimum & 15.128 & 9.266 & 20.989 & -0.008 & -0.018 & 0.002 & 0.86 \\
\hline
\end{tabular}

a Asymptotic 95\% confidence interval. 
the disease was greater in years with lower July and August daily minimum and maximum temperatures than in years with higher minimum and maximum temperatures.

Sclerotinia stem rot is a cool-climate disease, and the temperature-disease relationships observed in this investigation are in agreement with published reports $(1,24)$. For example, the normal maximum temperature for the 10 locations in Iowa and Minnesota ranged from 27.9 to $30.7^{\circ} \mathrm{C}$ in July and from 26.3 to $29.3^{\circ} \mathrm{C}$ in August. These temperatures are close to those described by various investigators above which development of Sclerotinia stem rot is retarded $(1,5,24)$. In this investigation, years that had greater negative cumulative departures from normal temperatures had considerably less prevalence of the disease than years that had positive departures. Therefore, the monthly normal maximum temperatures in July and August in north-central Iowa and southern Minnesota may serve as benchmarks for prediction of the possibility of Sclerotinia stem rot development in this region.

Both temperature and moisture are important factors in the development of Sclerotinia stem rot (1). In this investigation, however, no relationship was observed between precipitation and the prevalence of Sclerotinia stem rot. The lack of a relationship suggests that moisture may not have been limiting throughout the study. There may have been enough moisture for disease development throughout the course of the investigation that variation in
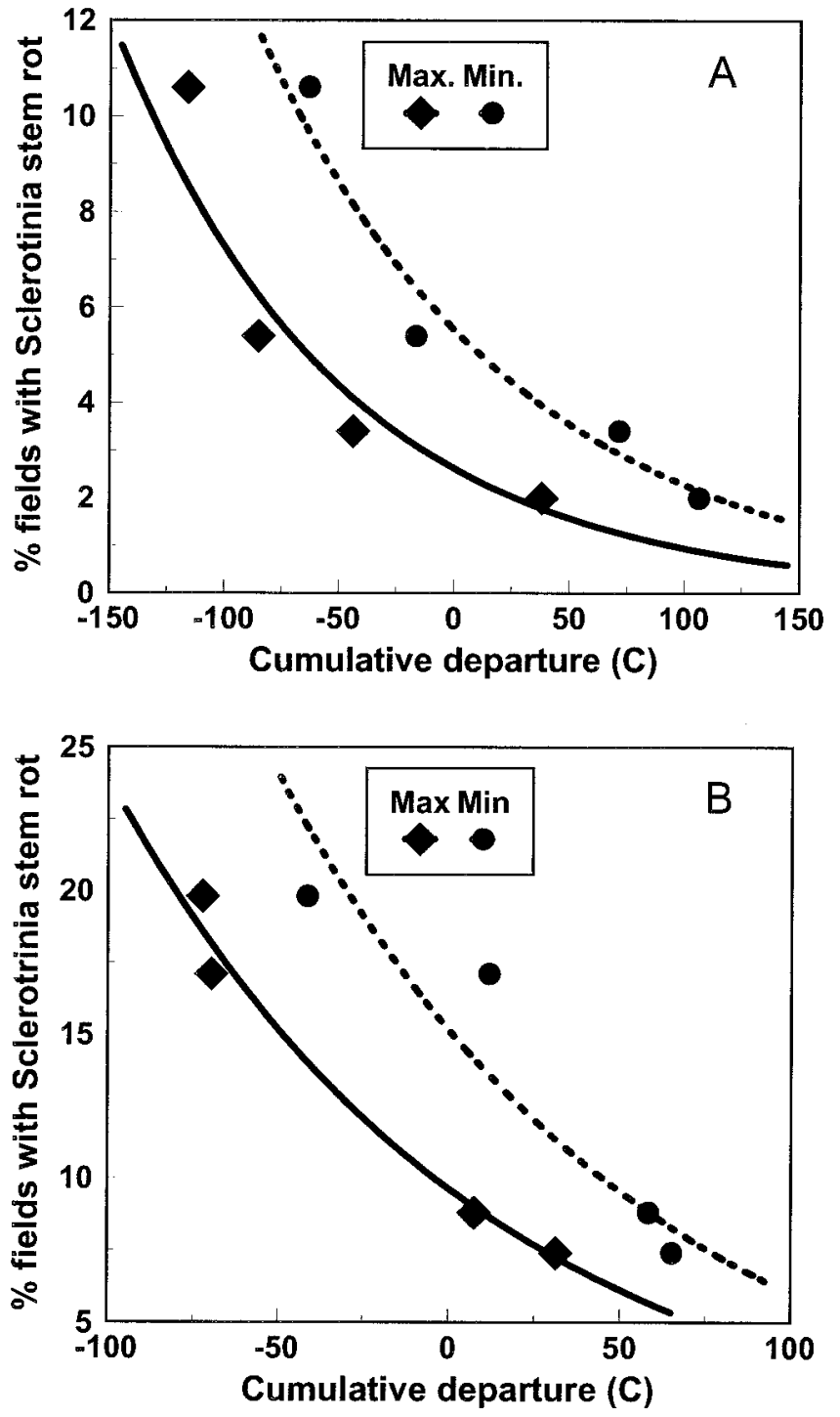

Fig. 4. Relationships between cumulative departures from normal maximum and minimum temperatures and the percentage of fields with Sclerotinia stem rot for A, Iowa and B, Minnesota in samples collected during 1995 to 1998. the amount of precipitation may not have made a difference. In Iowa, the amount and frequency of rain were similar in 1995 and 1996. The prevalence of the disease, however, was greater in 1996 than in 1995. In years in which there was less prevalence of disease, temperature may have been the major limiting factor. Grau and Radke (14) observed a similar phenomenon in Wisconsin, where Sclerotinia stem rot failed to develop in adequately irrigated soybean fields because of the prevailing high maximum and minimum temperatures during the soybean flowering period. It appears that there is more year-to-year variation in temperature than in precipitation, which suggests that temperature may be more critical than moisture under field conditions in the northcentral United States. In snap beans and dry beans, however, Abawi and Grogan (1) reported that temperature exerted a significant effect on apothecial production, ascospore germination and infection, and lesion expansion but concluded that temperature per

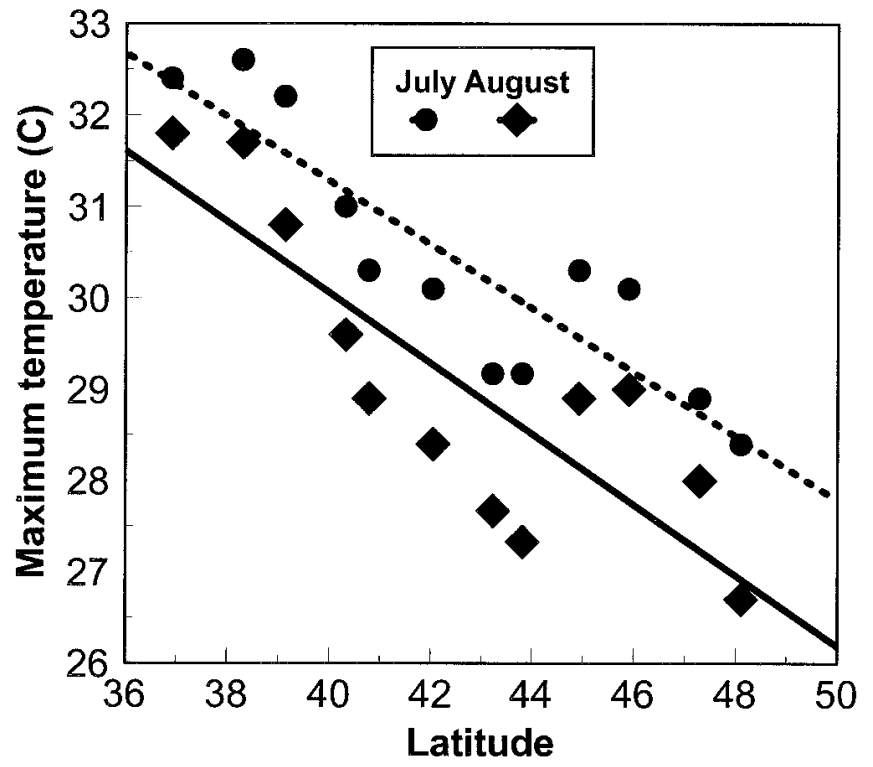

Fig. 5. Relationships between latitudinal positions and normal maximum temperatures for July and August (30-year average). The normal temperatures were obtained from 12 latitudinal locations between southern Missouri $\left(37^{\circ} \mathrm{N}\right)$ and northern Minnesota $\left(48^{\circ} \mathrm{N}\right)$ at approximately every $1^{\circ}$.

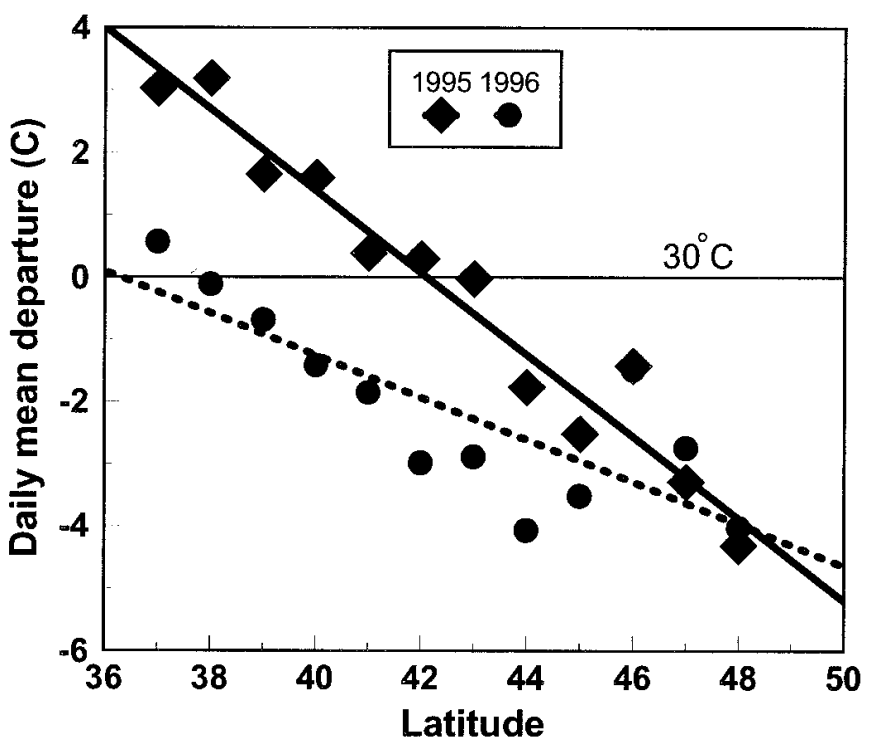

Fig. 6. Relationships between latitudinal positions and departures from the upper limit temperature $\left(30^{\circ} \mathrm{C}\right)$ for Sclerotinia stem rot development in 1995 and 1996. 
TABLE 2. Parameter estimates for the exponential model $\left(Y=a \times e^{\mathrm{bx}}\right)$ for relationships between latitudinal positions and prevalence of Sclerotinia stem rot of soybean in 1995 and 1996

\begin{tabular}{lcccccc}
\hline & \multicolumn{5}{c}{ Parameter estimates } \\
\cline { 2 - 7 } Model & $a$ & Lower limit $^{\mathrm{a}}$ & Upper limit & $b$ & Lower limit & Upper limit \\
\hline 1995 & 0.00004 & -0.00190 & 0.00027 & 0.23890 & 0.11853 & 0.35967 \\
1996 & 0.00182 & -0.00862 & 0.01262 & 0.16724 & 0.04565 & 0.28883 \\
\hline
\end{tabular}

a Asymptotic 95\% confidence interval.
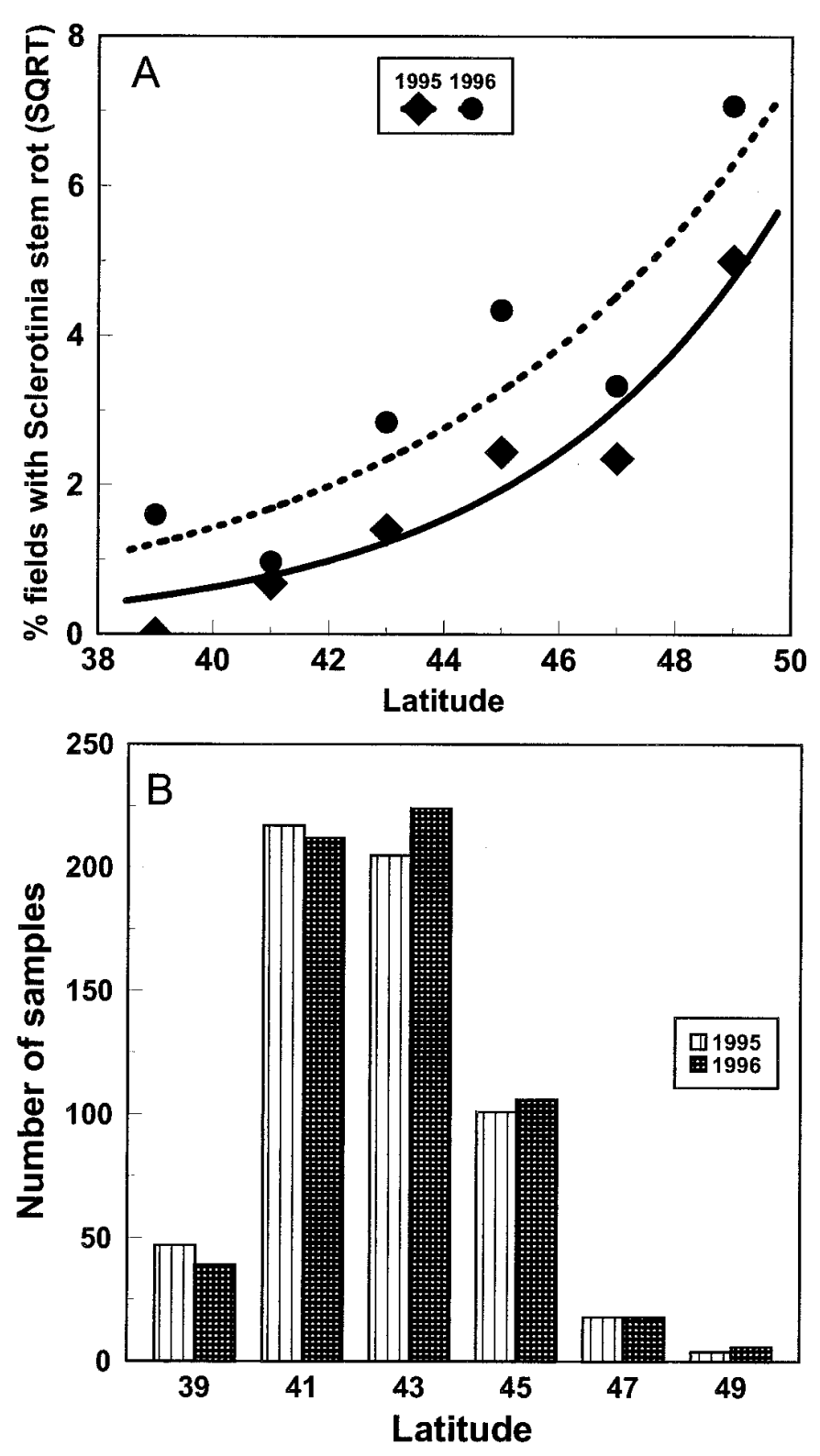

Fig. 7. A, Relationships between latitudinal positions and the square root of the percentage of fields in which Sclerotinia stem rot was detected. B, Number of samples from each latitudinal position.

se may not be a limiting factor under New York conditions. Similarly, in white beans in Ontario, Tu reported that disease spread was associated with frequency of precipitation and concluded that temperature does not appear to be restrictive in any year (21). Therefore, the limiting factor in the epidemiology of Sclerotinia stem rot may vary from region to region depending on year-toyear variations in temperature or precipitation.

Variations in temperature in the region due to latitudinal position affected the prevalence and distribution of sclerotinia stem rot. The prevalence of the disease increased exponentially with

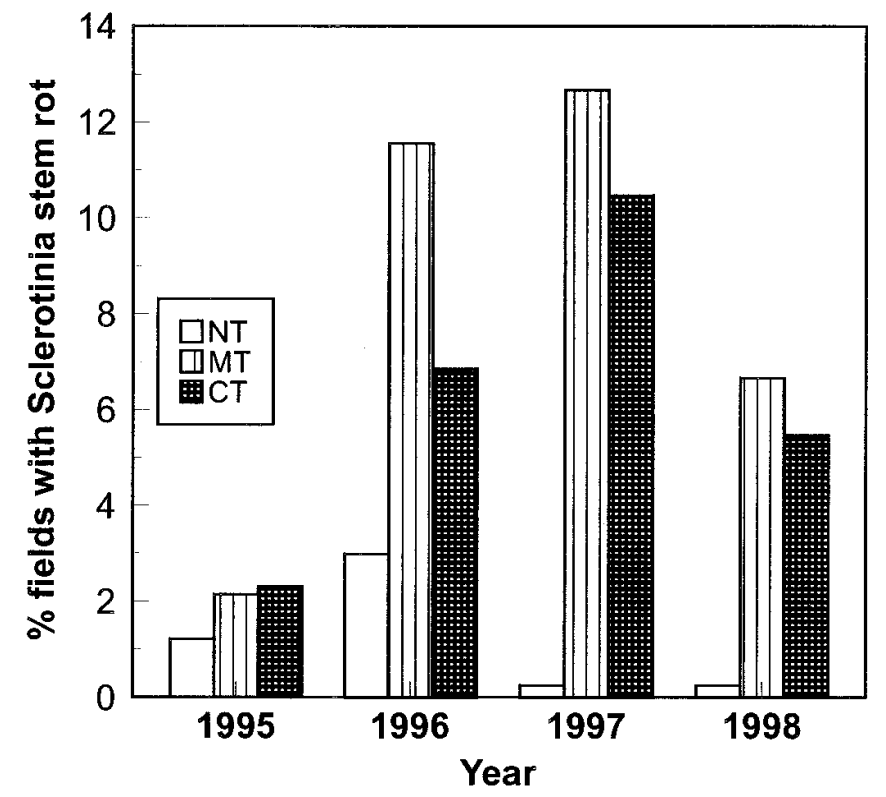

Fig. 8. Percentage of fields with Sclerotinia stem rot in no-till (NT), minimum-till (MT), and conventional-till (CT) from 1996 to 1998. The graph is the result of pooled data across four states (Illinois, Iowa, Minnesota, and Ohio). In 1995, sample sizes from NT, MT, and CT were 165, 187, and 260, respectively. In 1996, sample sizes were 167,225 , and 219 , respectively. In 1997, sample sizes were 22, 71, and 86, respectively. In 1998, sample sizes were 17, 90, and 91, respectively. Sclerotinia stem rot was not detected in Missouri during the 4-year period and was not included in the graph.

increasing latitude, reflecting north-south variations in temperature. At every latitude, the prevalence of the disease was greater in 1996 (cool summer) than in 1995 (warm summer). In 1996, Sclerotinia stem rot was detected at lower latitudes than in 1995, suggesting that during cool summer months, the disease can develop farther south in normally warmer areas of the north-central United States. It also indicates that the pathogen may be present in these areas but remains inactive during warm seasons. The implication is that the north-south distribution of the disease in any given year is dependent on temperature.

There were significant differences among tillage categories in prevalence of Sclerotinia stem rot. The prevalence of the disease was less in no-till fields than in either minimum-till or conventional-till fields. Generally, no-till fields have less dense canopies than minimum-till and conventional-till fields. In addition, in notill fields, sclerotia produced on the outside of the soybean stems drop on the ground and remain on the soil surface. The sclerotia on the soil surface may have been exposed to dry conditions that may have affected germination and subsequent infection and disease development. Another possible scenario is that in minimumtill and conventional-till fields, tillage operation and cultivation distribute sclerotia in the field, in effect changing the spatial pattern of the sclerotia from aggregate to near randomness as reported for sclerotia of $S$. minor (20). In no-till fields where there is little or no soil movement, however, the sclerotia remain more or less aggregated. This may have affected the probability of infected plants to be included in the samples. 


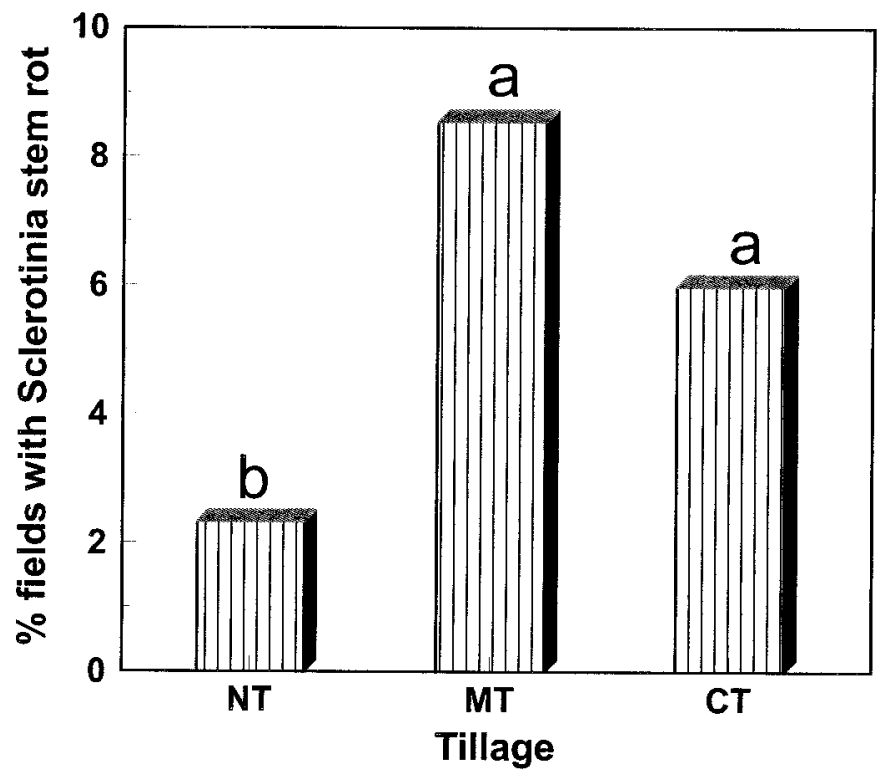

Fig. 9. Percentage of fields with Sclerotinia stem rot in no-till (NT), minimum-till (MT), and conventional-till (CT) fields pooled across years (1995 to 1998) and states (Illinois, Iowa, Minnesota and Ohio). Bars with the same letter are not significantly different $(P \leq 0.05)$ according to a chi-square test. Percentages are based on samples of 371, 573, and 656 for no-till, minimum-till, and conventional-till fields, respectively.

Soybean residue on the soil surface takes longer to decompose than buried residue (10). The role of sclerotia confined in infested stem residue on the soil surface in the epidemiology of the disease in no-till soybean fields is not known. It is possible, however, that the sclerotia confined in stem residues may not have been able to germinate because of the physical barrier. In no-till fields, only sclerotia at the opposite ends of undecomposed segments of soybean stems are often seen germinating (personal observation). The sclerotia of S. sclerotiorum are known to be colonized by numerous microorganisms, and thus it is reasonable to assume that the sclerotia inside the soybean stems may have been degraded by microorganisms during the long process of surface residue decomposition.

Garcia-Garza et al. (9) found more apothecia in minimum-till than in no-till fields, even though it did not result in detectable differences in disease incidence between the tillage treatments. In our study, minimum-till fields had greater prevalence of Sclerotinia stem rot than no-till or conventional-till fields. Under field conditions, sclerotia of $S$. sclerotiorum is known to produce apothecia with stipes 2 to $3 \mathrm{~cm}$ long (2). Thus, deep plowing is recommended as one of the conventional control tactics to bury the sclerotia beyond the emerging ability of apothecia. Minimum tillage is geared toward maintenance of surface residue with minimum soil disturbance as opposed to conventional tillage in which the bulk of surface soil is turned under. Minimum tillage, therefore, may place the sclerotia close to the soil surface in more suitable positions (neither too deep nor too dry) for emergence of apothecia than any other tillage operation as observed by GarciaGarza et al. (9). This may partly explain why minimum-till fields had greater prevalence of the disease than either no-till or conventional-till fields.

The results of this investigation are based on a 4-year survey that documented the presence or absence of Sclerotinia stem rot in soybean fields. Fields that had Sclerotinia stem rot did not differ in incidence of the disease regardless of the tillage system. In the north-central United States, tillage practices are now more diverse than at any time in the recent past. The results presented here are based on surveys, not controlled study. More investigations, therefore, are necessary to further unravel the relationships between various tillage practices (especially no-till and minimum-till) and Sclerotinia stem rot of soybeans.

\section{ACKNOWLEDGMENTS}

The research was supported by the Iowa Soybean Promotion Board, the North Central Soybean Research Program, the Hatch Act, and the State of Iowa Funds. Journal Paper 18630 of the Iowa Agriculture and Home Economics Experiment Station Project 2869. We thank H. Holden of the Iowa Department of Agriculture and Land Stewardship, Bureau of Agricultural Statistics, for coordination of stem sample collection by NASDA enumerators and for providing additional data about the sample sites. We thank A. L. Heil for technical assistance.

\section{LITERATURE CITED}

1. Abawi, G. S., and Grogan, R. G. 1975. Source of primary inoculum and effects of temperature and moisture on infection of beans by Whetzelinia sclerotiorum. Phytopathology 65:300-309.

2. Abawi, G. S., and Grogan, R. G. 1979. Epidemiology of diseases caused by Sclerotinia species. Phytopathology 69:899-904.

3. Anonymous. 1998. Crop Residue Management: Midwest Region. Conservation Technology and Information Center, West Lafayette, IN.

4. Blad, B. L., Steadman, J. R., and Weiss, A. 1978. Canopy structure and irrigation influence white mold disease and microclimate of dry edible beans. Phytopathology 68:1431-1437.

5. Boland, G. J., and Hall, R. 1987. Epidemiology of white mold of bean in Ontario. Can. J. Plant Pathol. 9:218-224.

6. Boland, G. J., and Hall, R. 1988. Epidemiology of Sclerotinia stem rot of soybean in Ontario. Phytopathology 78:1241-1245.

7. Boland, G. J., and Hall, R. 1994. Index of plant hosts of Sclerotinia sclerotiorum. Can. J. Plant Pathol. 16:93-108.

8. Cotter, J., and Nealon, J. 1987. Area frame design for agricultural surveys. USDA-NASS, Washington, DC.

9. Garcia-Garza, J. A., Boland, G. J., and Vyn, T. J. 1998. Influence of crop rotation and reduced tillage on white mold of soybean caused by Sclerotinia sclerotiorum. (Abstr.) Phytopathology 88(suppl.):S533.

10. Ghidey, F., and Alberts, E. E. 1993. Residue type and placement effects on decomposition: Field study and model evaluation. Am. Soc. Agric. Eng. 36:1611-1617.

11. Gomez, K. A., and Gomez, A. A. 1984. Statistical Procedures for Agricultural Research. 2nd. ed. John Wiley, New York.

12. Grau, C. R. 1989. Sclerotinia stem rot. Pages 47-48 in: Compendium of Soybean Diseases. J. B. Sinclair and P. A. Backman, eds. 3rd ed. The American Phytopathological Society, St. Paul, MN.

13. Grau, C. R. 1994. An integrated approach to control of Sclerotinia stem rot (white mold) in soybean. Pages 183-196 in: Proc. Integr. Crop Manage. Conf. Iowa State University Extension, Ames.

14. Grau, C. R., and Radke, V. L. 1984. Effects of cultivars and cultural practices on Sclerotinia stem rot of soybean. Plant Dis. 68:56-58.

15. Phillips, A. J. L. 1994. Influence of fluctuating temperature and interrupted periods of plant surface wetness on infection of bean leaves by ascospores of Sclerotinia sclerotiorum. Ann. Appl. Biol. 124:413-427.

16. Purdy, L. H. 1979. Sclerotinia sclerotiorum: Disease and symptomology, host range, geographic distribution, and impact. Phytopathology 69:875880 .

17. Schwartz, H. F., Steadman, J. R., and Coyne, D. P. 1978. Influence of Phaseolus vulgaris blossoming characteristics and canopy structure upon reaction to Sclerotinia sclerotiorum. Phytopathology 68:465-470.

18. Steadman, J. R. 1983. White mold-A serious yield-limiting disease of soybean. Plant Dis. 67:346-350.

19. Steadman, J. R., Coyne, D. P., and Cook, G. E. 1973. Reduction of severity of white mold disease on great northern beans by wider row spacing and determinate plant growth habit. Plant Dis. Rep. 57:1070-1071.

20. Subbarao, K. V., Koike, S. T., and Hubbard, J. C. 1996. Effect of deep plowing on the distribution and density of Sclerotinia minor sclerotia and lettuce drop incidence. Plant Dis. 80:28-33.

21. Tu, J. C. 1989. Management of white mold of white beans in Ontario. Plant Dis. 73:281-285.

22. United States Department of Agriculture. 1983. Scope and methods of statistical reporting service. Misc. Publ. 1308.

23. Weiss, A., Hipps, L. E., Blad, B. L., and Steadman, J. R. 1980. Comparison of within-canopy microclimate and white mold disease (Sclerotinia sclerotiorum) development in dry edible beans as influenced by canopy structure and irrigation. Agric. Meteorol. 22:11-21.

24. Weiss, A., Kerr, E. D., and Steadman, J. R. 1980. Temperature and moisture influence on development of white mold disease (Sclerotinia sclerotiorum) on great northern beans. Plant Dis. 64:757-759. 
25. Williams, J. R., and Stelfox, D. 1980. Influence of farming practices in Alberta on germination and apothecium production of Sclerotinia sclerotiorum. Can. J. Plant Pathol. 2:196-172.

26. Workneh, F., Tylka, G. L., Yang, X. B., Faghihi, J., and Ferris, J. M. 1999. Regional assessment of soybean brown stem rot, Phytophthora sojae, and Heterodera glycines using area-frame sampling: Prevalence and effects of tillage. Phytopathology 89:204-211.

27. Wrather, J. A., Anderson, T. R., Arsyad, D. M., Gai, J., Plopper, L. D.,
Porta-Puglia, A., Ram, H. H., and Yorinori, J. T. 1997. Soybean disease loss estimates for the top 10 soybean-producing countries in 1994. Plant Dis. 81:107-110.

28. Yang, X. B., Lundeen, P., and Uphoff, M. D. 1999. Soybean varietal response and yield loss caused by Sclerotinia sclerotiorum. Plant Dis. 83:456-461.

29. Zadoks, J. C., and Schein, R. C. 1979. Epidemiology of Plant Disease Management. Oxford University Press, Oxford. 